\title{
Клінічний випадок пізньої форми сифілісу у хворої на вульгарний пемфігус
}

\author{
I.О. Олійник, А.Е-С.Е-С. Абдалла, В.В. Кутова \\ ДУ «Інститут дерматології та венерології НАМН України»
}

\begin{abstract}
Резюме
Мета роботи. Зменшити кількість діагностичних помилок у разі вульгарного пемфігусу та пізніх форм сифілісу для покращення якості життя та запобігти передчасним випадкам летальності у хворих на вульгарний пемфігус. Підвищити обізнаність лікарів щодо використання трепонемних тестів для уточнення діагнозу пізніх форм сифілісу.

Матеріали і методи. Описано випадок вульгарного пемфігусу, діагностований на підставі клінічної картини, даних анамнезу, результатів цитологічного дослідження. Діагностовано супутню патологію - пізній прихований сифіліс - завдяки проведенню комплексу серологічних досліджень: нетрепонемні та трепонемні тести (реакція мікропреципітації (РМп), імуноферментний аналіз сумарний (ІФАсум.) - IgG+IgM, реакція пасивної гемаглютинації (РПГА), реакція імунофлюоресценції з абсорбцією (РІФабс.) та ІФА-Different.

Результати. При динамічному спостереженні та обстеженні хворої на вульгарний пемфігус було виявлено пізній прихований сифіліс на підставі позитивних трепонемних тестів: ІФАсум. (lgG+lgM) - позитивний, якісна РПГА «4+» - позитивна; напівкількісна РПГА 1:8 «2+» - позитивна; РІФабс. «3+» - позитивна. Для верифікації діагнозу проведено дослідження зразка сироватки за методом ІФА-Different.
\end{abstract}

Висновки. Завдяки широкому комплексу проведених серологічних досліджень і консультації суміжних спеціалістів у хворої на вульгарний пемфігус діагностовано пізній прихований сифіліс.

Ключові слова: вульгарний пемфігус, комплекс серологічних тестів, пізній прихований сифіліс.

DOI: 10.33743/2308-1066-2021-2-35-38

\section{Вступ}

Вульгарний пемфігус (ВП) належить до групи рідкісних аутоімунних захворювань, потенційно загрожує життю людини за рахунок порушення цілістності шкіри та слизових оболонок [8]. Бульозні елементи та ерозіі, що формуються, є наслідком синтезу антитіл до глікопротеїнів десмосомального апарату кератиноцитів. Цей механізм призводить до втрати міжклітинної адгезіі, інтраепідермального накопичення рідини та формування булл з дряблою покришкою, при руйнуванні якої утворюються ерозії [9]. Щороку на 100000 населення реєструють 0,5-3,2 випадку захворювання. Частіше хворіють особи 50-60-річного віку у співвідношенні чоловіки/жінки - 1/2 [7].

У $80-90 \%$ хворих на ВП уражається слизова оболонка рота, в 60\% пацієнтів первинною ознакою захворювання є ерозії на слизовій рота [6]. У результаті первинне лікування хворі отримують у стоматологів, інфекціоністів та алергологів з приводу афтозного стоматиту, герпетичного стоматиту, виразково-некротичного стоматиту, десквамативного гінгівіту, багатоформної ексудативної еритеми, папульозного сифіліду слизових оболонок (ерозивна або виразкова форма) тощо.

Отже, суміжні фахівці мають бути обізнаними з приводу диференційної діагностики цих захворювань і в першу чергу проводити цитологічне дослідження ерозивних елементів і вмісту бульозних елементів на наявність акантолітичних клітин.

На відміну від ВП, для афтозного стоматиту характерним є утворення обмежених болючих ерозій, вкритих сіро-гнійним нальотом, по периферії ерозії - яскраво-червоний обідок, симптом Нікольського - негативний, акантолітичні клітини при цитологічному дослідженні не виявляються [4].

Первинними проявами герпетичного стоматиту є підвищення температури тіла, гіперемія слизової рота і формування дрібних згрупованих пухирів. Захворювання має інфекційну етіологію і не залежить від віку й статі особи [3].

Багатоформна ексудативна еритема (БЕЕ) і виразково-некротичний стоматит (BНС) характеризуються гострим початком із підвищенням температури тіла до субфебрильних цифр. Міхури при БЕЕ мають пупкоподібне вдавлення по центру і розташовані на еритематозному фоні, тоді як висип при ВНС характеризується наявністю виразок і некрозу слизової оболонки ротової порожнини. Симптом Нікольського - негативний, акантолітичні клітини при цитологічному дослідженні не виявляються [2].

Папульозний сифілід слизових оболонок (syphilis papulosa mucosa) частіше зустрічається у жінок при вторинному сифілісі. Папули мають різко обмежені чіткі контури діаметром до 1,0 см овальної або округлої форми 
з червоно-фіолетовим відтінком. У деяких випадках вони еволюціонують в ерозії (syphilis papulosa erosiva mucosae) або виразки (syphilis papulosa exulceraus mucosae). Поверхня ерозій або виразок найчастіше вкрита жовто-сірим нальотом або гнійними масами. Від здорових ділянок ерозії та виразки відмежовані чітким інфільтрованим вінчиком фіолетово-червоного кольору [1].

На шкірі можуть спостерігатися ерозивні папульозні сифіліди (syphilis papulosa erosiva) та виразкові папульозні сифіліди (syphilis papulosa exulcerans) як наслідок мацерації поверхні папульозних сифілідів. Від здорових ділянок шкіри вони відмежовані папульозним обідком. Улюблена локалізація - природні складки шкіри або слизових (у кутах рота, навколо очей, анальні складки, міжпальцеві проміжки стоп), мають вигляд глибоких тріщин [5].

3 метою запобігання діагностичним помилкам, пов'язаним із рідкістю ВП і різних форм сифілісу, які призводять до тривалого неефективного лікування, порушення якості життя і в деяких випадках - до летальних наслідків, наведено клінічний випадок спостереження за хворою на ВП, в якої було діагностовано пізній прихований сифіліс.

\section{Матеріали і методи}

Описано випадок ВП, який діагностовано на підставі клінічної картини, даних анамнезу, результатів цитологічного дослідження. Виявлено супутню патологію - пізній прихований сифіліс - завдяки проведенню комплексу серологічних досліджень: нетрепонемні та трепонемні тести (РМП, IФАсум. (IgG+IgM), РПГА, РІФабс., ІФА-Different).

\section{Результати}

Хвора жінка С., 46 років, була направлена на консультацію та лікування до ДУ «ІДВ НАМН України» зі скаргами на висип на шкірі обличчя, тулуба, верхніх і нижніх кінцівок, слизових ротової порожнини й носа, червоній облямівці губ, болючість у місцях висипу, труднощі при прийомі їжі та ковтанні.

3 анамнезу хвороби відомо, що первинний висип з'явився у грудні 2018 р. на слизовій рота, з приводу чого лікувалась у стоматолога. Протягом року отримувала терапію виразкового й афтозного стоматиту (системні антибіотики пеніцилінового і цефалоспоринового ряду, антимікотики, ранозагоювальні засоби) з тимчасовим ефектом. У січні 2020 р. $з$ приводу чергового загострення звернулась до інфекціоніста, отримувала терапію з приводу герпетичного стоматиту противірусними й імуномодулювальними препаратами. Після завершення курсу терапії дерматоз поширився на шкіру обличчя, тулуба, кінцівок. Хвору направили на консультацію до дерматолога.

За результатом огляду й обстеження (при цитологічному дослідженні матеріалу з дна ерозії та бульозних елементів на шкірі виявлені акантолітичні клітини) дерматологом встановлений діагноз: «Вульгарний пемфігус».

Лікувальна схема складалась із базової терапії: системний глюкокортикостероїд (СГКС) у добовій дозі 100 мг у перерахунку на преднізолон, а також цитостатик - імуран у добовій дозі 100 мг. Додатково отримувала блокатор протонної помпи, препарати кальцію і калію. Спостерігалась тенденція до регресування елементів висипу. Розпочата програма поступового зниження дози СГКС. На дозі 45 мг/добу за преднізолоном і дозі імурану 50 мг/добу відзначався рецидив захворювання.

У жовтні 2020 р. була направлена на консультацію до ДУ «ІДВ НАМНУ». На момент госпіталізації звертало на себе увагу тремтіння верхніх кінцівок. Дерматоз мав дисемінований характер із залученням слизової оболонки ротової порожнини, червоної облямівки губ, шкіри обличчя, верхньої третини тулуба.

Червона облямівка губ вкрита масивними багатошаровими серозними кірками, що ускладнювало відкриття рота і прийом їжі (рис. 1). На слизовій ротової порожнини (твердому і м'якому піднебінні, спинці і бокових поверхнях язика, під’язиковій ділянці, слизовій щік і ясен) численні ерозивні дефекти розміром від 0,5 до 2,0 см у діаметрі, вистелені білим нальотом з обривками епітелію по периферії. У кутах губ - лінійні тріщини, які кровоточать.

В'ялі булли наповнені серозним вмістом, розташовані на незміненому фоні, мають діаметр від 0,5 до 7,0 см. Крайовий симптом Нікольського позитивний. Ерозії овальної форми, розташовані на незміненому фоні, подекуди зливаються між собою, розміром від 0,5 до 12 см у діаметрі, з масивними серозно-геморагічними нашаруваннями кірок.
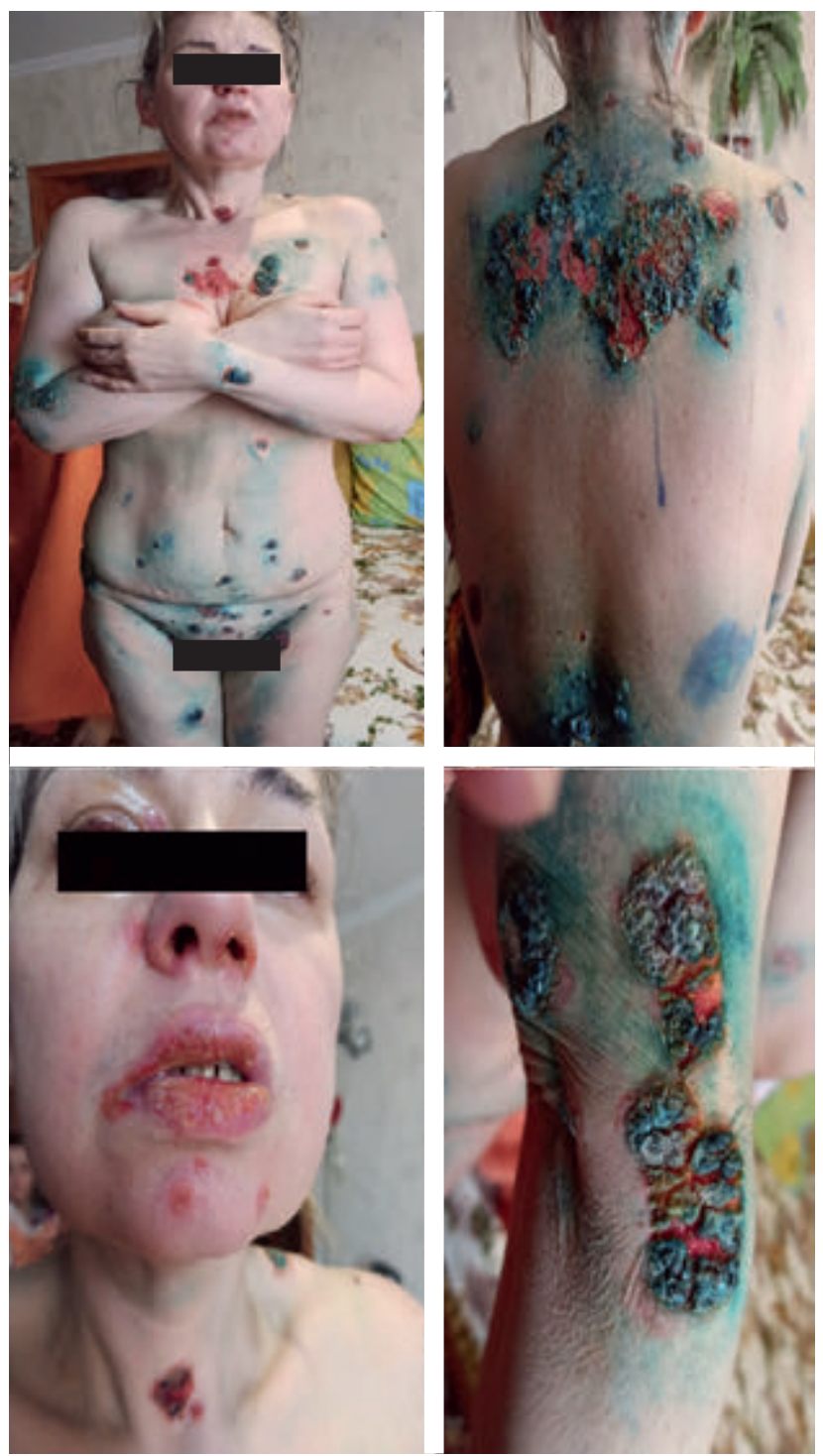

Рис. 1. Хвора С., діагноз: “Вульгарний пемфігус», до лікування 


\section{КЛІНІЧНІ ВИПАДКИ}

3 анамнезу життя відомо, що алергологічний анамнез і спадковість не обтяжені; туберкульоз, вірусні гепатити заперечує. Повідомила, що 10 років тому отримувала курс терапії в анонімному кабінеті з приводу сифілісу разом із чоловіком. Тривалість терапії, кратність уведення антибіотиків, назву антибіотика і кількість курсів не пам'ятає.

Консультована невропатологом. Встановлено: тривожно-депресивний розлад. Постуральноміметичний розлад. Ецефалопатія невідомої етіології. Рекомендовано: МРТ головного мозку; серологічне дослідження ліквору.

Клініко-лабораторне обстеження: клінічний аналіз крові, клінічний аналіз сечі, біохімічні показники крові і показники згортальної системи крові - без патологічних змін. Під час цитологічного дослідження матеріалу 3 дна ерозій на слизовій рота були виявлені поодинокі акантолітичні клітини - групами по 2-5 у полі зору; запальний інфільтрат рясний, представлений сегментоядерними лейкоцитами; мікрофлора - диплококи, палички.

При проведенні комплексу серологічних реакцій на сифіліс отримані такі результати: нетрепонемні тести: РМП - негативна; трепонемні тести: ІФАсум. ( IgG+IgM) - позитивний, якісна РПГА «4+» - позитивна; напівкількісна РПГА 1:8 «2+»- позитивна; РІФабс. «3+» - позитивна. Для верифікації діагнозу проведено дослідження зразка сироватки за методом IФA-Different (різновид імуноблоту). Отримані такі показники: TpN15' TpN17' TpN41 та TpN47 - позитивні, що свідчить про наявність імуноглобулінів до всіх 4 білків Treponema pallidum.

Отже, на підставі проведеного комплексного клініко-лабораторного обстеження, детального збору анамнезу, консультативного висновка невропатолога хворій був встановлений діагноз: «Вульгарний пемфігус, кортикостероїдзалежна форма». Супутній діагноз: «Пізній прихований сифіліс. Тривожно-депресивний розлад. Постурально-міметичний розлад. Ецефалопатія невідомої етіології».

За час госпіталізації в клініці Інституту хвора отримувала терапію: СГКС і цитостатик з поступовим зниженням дози, системний антибактеріальний препарат тетрациклінового ряду (хворим на ВП протипоказане застосування антибіотиків пеніцилінового та цефалоспоринового ряду), симптоматичну терапію (препарати $\mathrm{K}^{+}, \mathrm{Ca}^{2+}$, гастро- і гепатопротектор). Зовнішня терапія полягала в полосканні ротової порожнини,

\section{Література}

1. Караков К.Г. Проявление сифилиса в полости рта: учебное пособие. Ставрополь: 000 «Издательско-информционный центр «Фабула»», 2012. 84 с

2. Луцкая И.К. Язвенно-некротический стоматит у взрослых и детей: диагностика, леение и профилактика. Современная стоматология. 2018. № 2. С. 17-20.

3. Організація, діагностика і комлексне лікування герпетичного стоматиту. Навчальний сібник / Р.В. Казакова, Є.Я. Костенко, В.С. Мельник та ін. Ужгород, 2016. 186 с.

4. Ошибка в диагностике вульгарной пузырчатки: клинический случай / И.В. Хамаганова, Е.Н. Маляренко, Е.В. Денисова и др. Российский журнал кожных и венерических болезней. 2017. Т. 20. № 1 С. 30-33.

5. Практические аспекты серологической диагностики сифилиса на современном этапе Я.Ф. Кутасевич, В.В. Кутовая, О.Н. Белоконь и др. Дерматологія та венерологія. 2020

6. Pemphigus vulgaris / A.M. Porro, C.A. Seque, M.C. Ferreira et al. Anais Brasileiros de 7. Pegia. 2019. Vol. 94, Iss. 3. P. 264-278

7. Pemphigus Vulgaris and Pemphigus Foliaceus: Differences in Epidemiology and Mortality Kridin, S. Zelber-Sagi, R. Bergman. Acta Derm Venereol. 2017. Vol. 97. P. 1095-1099. 8. Pemphigus; Dermatology / M. Amagai, J.L. Bolognia, J.V. Schaffer et al. 4th ed. New York: 9. The pathog. 494-509.

Clin Exp Dermatol. 2011. Vol. 36. № 7. P. 703-707.
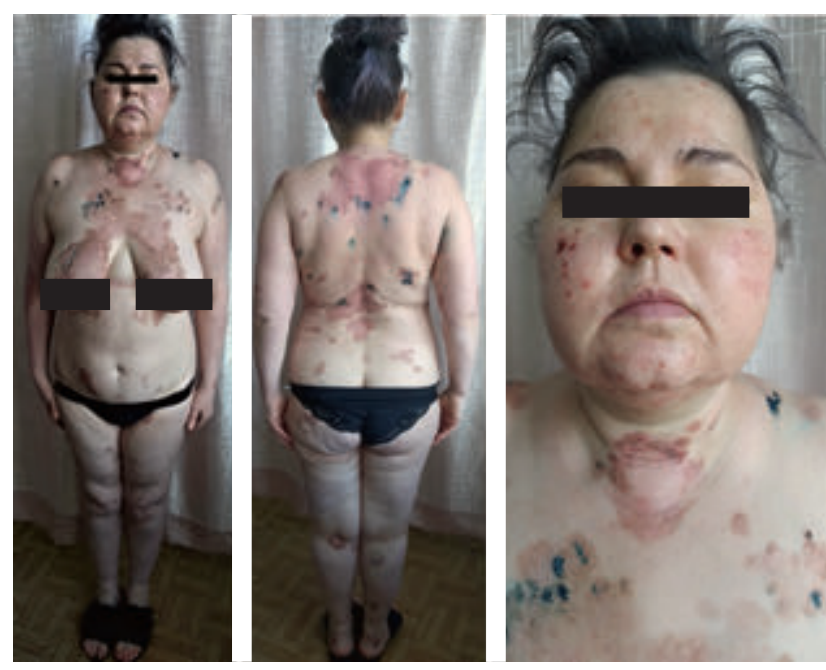

Рис. 2. Хвора С., діагноз: «Вульгарний пемфігус», після лікування

ванночках з антисептичними і дезінфікувальними розчинами, застосуванні водного анілінового барвника, ранозагоювальних місцевих препаратів.

Хвора була виписана у стані клінічної ремісії з приводу ВП і з рекомендаціями щодо завершення курсу терапії з приводу пізнього прихованого сифілісу згідно з протоколом, викладеним у наказах МОЗ України № 286 від 07.06.2004 і додатку до наказу № 312 від 08.05.2009 (рис. 2).

\section{Висновки}

Описане клінічне спостереження цікаве з огляду на складність встановлення діагнозу ВП на ранніх етапах. Це пов’язано з первинними проявами захворювання на слизових оболонках і зверненням пацієнтів до суміжних фахівців. Відсутність терапевтичного ефекту й ураження шкіри змушує хворих звертатися за консультацією до дерматолога. За результатами обстеження був встановлений діагноз ВП і призначена терапія, що мала позитивний ефект.

Враховуючи загострення дерматозу на високих дозах імуносупресивної терапії, на підставі аналізу анамнезу хвороби, оцінки неврологічного статусу (консультація невропатолога) і проведеного комплексу серологічних реакцій (специфічні трепонемні тести) у хворої на ВП було діагностовано пізній прихований сифіліс. Завдяки проведеному специфічному антибактеріальному курсу терапії з приводу елімінації T. pallidum було досягнено підтримувальної дози СГКС 25 мг/добу та епітелізації ерозивних елементів.

\section{References}

1. Karakov KG. Proyavlenie sifilisa v polosti rta: uchebnoe posobie [Manifestation of syphilis in the oral cavity: a study manual]. Stavropol: 000 «Izdatelsko-informtsionnyiy tsentr «Fabula» 2012. 84 p.

2. Lutskaya IK. Yazvenno-nekroticheskiy stomatit u vzroslyih i detey: diagnostika, lechenie i profilaktika [Ulcer and necrotic stomatitis at adults and children: diagnostics, treatment and prevention]. Sovremennaya stomatologiya. 2018;2:17-20.

3. Kazakova RV, Kostenko EYa, Melnik VS, et al. Organizatsiya, diagnostika i komleksne likuvannya gerpetichnogo stomatitu [Organization, diagnosis and complex treatment of herpetic stomatitis]. Uzhgorod. 2016; $186 \mathrm{p}$.

4. Hamaganova IV, Malyarenko EN, Denisova EV, et al. Oshibka v diagnostike vulgarnoy puzyirchatki: klinicheskiy sluchay [Mistakes of diagnostics in pemphigus vulgari: case report].

5. Kutasevich YaF, Kutovaya VV, Belokon ON, et al. Prakticheskie aspektyi serologicheskoy diagnostiki sifilisa na sovremennom etape [Practical aspects of the serological diagnosis of syphis at the present stage]. Dermatologlya ta venerologlya. 2020;1(87):39-43.

6. Porro AM, Seque CA, Ferreira MC, et al. Pemphigus vulgaris. Anais Brasileiros de Dermatologia. 2019;94(3):264-278.

7. Kridin K, Zelber-Sagi S, Bergman R. Pemphigus Vulgaris and Pemphigus Foliaceus: Differences in Epidemiology and Mortality. Acta Derm Venereol. 2017;97:1095-1099.

8. Amagai M, Bolognia JL, Schaffer JV, et al. Pemphigus. Dermatology. 4th ed. New York: Elsevier, 2018. P. 494-509

9. Pan M, Liu X Zheng J. The pathogenic role of autoantibodies in pemphigus vulgaris. Clin Exp Dermatol. 2011;36(7):703-707. 


\title{
КЛИНИЧЕСКИЙ СЛУЧАЙ ПОЗДНЕЙ ФОРМЫ СИФИЛИСА У БОЛЬНОЙ ВУЛЬГАРНОЙ ПУЗЫРЧАТКОЙ
}

\author{
И.А. Олейник, А.Э-С.Э-С. Абдалла, В.В. Кутовая
}

ГУ «Институт дерматологии и венерологии НАМН Украины»

\section{Резюме}

Цель. Уменьшить количество диагностических ошибок относительно вульгарной пузырчатки и поздних форм сифилиса для улучшения качества жизни и предотвратить преждевременные случаи летальных исходов у больных вульгарной пузырчаткой. Повысить осведомленность врачей по поводу применения трепонемных тестов для уточнения диагноза поздних форм сифилиса. Материалы и методы. Описан случай вульгарной пузырчатки, диагностированный на основании клинической картины, данных анамнеза, результатов цитологического исследования. Также диагностирована сопутствующая патология - поздний скрытый сифилис - благодаря проведенному комплексу серологических исследований: нетрепонемные и трепонемные тесты (реакция микропреципитации (РМП), иммуноферментный анализ суммарный (ИФАсумм.) - IgG+lgM, реакция пассивной гемагглютинации (РПГА), реакция иммунофлуоресценции с абсорбцией (РИФабс.), ИФА-Different.

Результаты. В результате динамического наблюдения и обследования больной, страдающей вульгарной пузырчаткой, был выявлен поздний скрытый сифилис на основании положительных трепонемних тестов: ИФАсум. (IgG+lgM) - положительный, качественная РПГА «4+» - положительная; полуколичественная РПГА 1:8 «2+» - положительная; РИФабс. «З+» - положительная. Для верификации диагноза проведено исследование образца сыворотки методом ИФА-Different.

Выводы. Благодаря широкому комплексу проведенных серологических тестов и консультации смежных специалистов у больной вульгарной пузырчаткой диагностирован поздний скрытый сифилис.

Ключевые слова: вульгарная пузырчатка, комплекс серологических тестов, поздний скрытый сифилис.

\section{A CASE OF LATE SYPHILIS IN A PATIENT WITH PEMPHIGUS VULGARIS}

\author{
I.O. Oliinyk, A.E-S. E-S. Abdalla, V.V. Kutovaya \\ $S E$ «Institute of Dermatology and Venereology of NAMS of Ukraine»
}

\section{Abstract}

The objective. Decrease the number of diagnostic mistakes of pemphigus vulgaris and late forms of syphilis to improve quality of life and prevent premature death in patients with pemphigus vulgaris. Raise doctors' awareness of the use of treponemal tests to clarify the diagnosis of late forms of syphilis.

Materials and methods. The case of pemphigus vulgaris determined on the basis of clinical picture, anamnesis, cytological examination results is described. A concomitant pathology was diagnosed, i.e., late syphilis due to the complex of serological tests: nontreponemal and treponemal (Venereal Disease Research Laboratory test (VDRL), Enzyme-Linked Immuno Sorbent Assay (ELISA), T. pallidum Haemagglutination Assay (TP-HA), Fluorescent Treponemal Antibody Absorption test (FTA abs), ELISA-Different).

Results. At dynamic supervision and inspection of the patient on pemphigus vulgaris and late syphilis on the basis of positive treponemal tests was revealed: ELISA sums. (IgG+lgM) - positive, high-quality TP-HA «4+» - positive; semi-quantitative TP-HA 1: 8 «2+» positive; FTA abs «3+» - positive. To verify the diagnosis, a serum sample was examined by ELISA-Different method.

Conclusions. Due to a wide range of serological research and consultation of related specialists, late syphilis was diagnosed in a pemphigus vulgaris patient.

Key words: pemphigus vulgaris, serological test kit, late syphilis.

Відомості про авторів:

Олійник Ірина Олександрівна - д-р мед. наук, ст. наук. співроб., головний наук. співроб. відділу дерматології, інфекційних та паразитарних захворювань шкіри ДУ «Інститут дерматології та венерології НАМН України»

ORCID ID: http://orcid.org/0000-0002-6408-830X

Абдалла Алія Ель-Саед Ель-Седик - аспірант відділу дерматології, інфекційних та паразитарних захворювань шкіри ДУ «Інститут дерматології та венерології НАМН України»; e-mail: aliya.abdalla04@gmail.com

ORCID ID: $h$ ttps://orcid.org/0000-0002-6180-549X

Кутова Валентина Василівна - канд. мед. наук, ст. наук. співроб., зав. лабораторії серології Ду «Інститут дерматології та венерології НАМН України»

ORCID ID: $h$ ttps://orcid.org/0000-0002-0799-797X 